\title{
Testing a Comprehensive Model of Organizational Justice Perceptions and Personal States with Personal and Organizational Outcomes
}

\author{
Aharon Tziner ${ }^{1}$, Erich C. Fein ${ }^{2} \&$ Cristinel Vasiliu ${ }^{3}$ \\ ${ }^{1}$ Netanya Academic College, Netanya, Israel \& Peres Academic Center, Rehovot, Israel \\ ${ }^{2}$ School of Psychology and Counselling, University of Southern Queensland, Toowoomba, QLD, Australia \\ ${ }^{3}$ The Bucharest University of Economic Studies, Romania \\ Correspondence: Aharon Tziner, Peres Academic Center, Rehovot, Israel. E-mail: atziner@netanya.ac.il
}

Received: November 21, 2019

Accepted: December 28, 2020

Online Published: January 13, 2020

doi:10.5539/ijbm.v15n2p17

URL: https://doi.org/10.5539/ijbm.v15n2p17

\begin{abstract}
Managers need to understand the types of perceptions, feelings, and reactions they should elicit from personnel under their direction. To this end, a parsimonious model is required. However, few comprehensive models linking managerial behaviours to employee states and outcomes have been developed and tested. Accordingly, this research articulates the importance of three critical constructs - leader-member exchange (LMX), job satisfaction, and perceived organizational justice - and associations with emotional exhaustion, work motivation, workplace misbehavior, and emotional intelligence as a concise and efficient model that explains the relationships between attitudes and states within individuals, and related, important work and personal outcomes. The model displayed a very high level of reliability and validity based on the exceptional fit of the structural equation models across two very large samples (over 1600 participants in each study).
\end{abstract}

Keywords: LMX, job satisfaction, organizational justice, burnout, emotional exhaustion, work motivation, leadership development, management development

\section{Introduction}

When managers are learning about employees they need to understand what types of perceptions, feelings, and reactions they should elicit from personnel under their direction. To this end, a parsimonious but usable model is required to motivate and sustain managers (Hunt, 1982). Such a model must primarily address employee perceptions, feelings and reactions that are vital antecedents to important outcomes (Vroom \& Jago, 1988). Management development interventions might be applied as components of experiential learning frameworks (White, 1992) or coaching methods (McCarthy \& Millner, 2013; Milner, McCarthy, \& Milner, 2018), but regardless of the method, managers would generally benefit from a model that would make salient the tacit links between managerial behaviors and employee attitudes and states. We note that such models must be embedded in social psychological theories and processes such as leadership mechanisms and attitude formation (Rast, Axtell, \& McGlynn, 2016).

The notion of "individual mechanisms" or "personal states" can be used to express the amalgam of employee perceptions, feelings, attitudes, and internal reactions that reflect the dynamic internal states of employees that are embedded in larger organizational contexts (Colquitt, LePine, \& Wesson, 2009). These mechanisms have included attitudes such contentedness with one's job (job satisfaction) and perceptions of organizational justice, in addition to as dynamic states such as motivation (Colquitt, et al., 2009), although the more specific mechanisms underlying perceptions and attitude change and formation can be further articulated via central theories within social psychology (Zimbardo \& Leippe, 1991). Within the research presented in this paper, we focus on connections between a delimited, parsimonious set of attitudes - perceptions of organizational justice, and job satisfaction - in conjunction with the dynamic personal states of leader-member exchange (LMX), motivation, and emotional exhaustion. These attitudes and personal states have consistently been shown to explain large amounts of variability in critical outcomes such as turnover (Bernerth \& Walker, 2012), work performance (Wang, Liao, Xia, \& Chang, 2010), and burnout (Faragher, Cass, \& Cooper, 2013). It would be important, for example, for new managers to realize that perceived organizational injustice is a key driver of workplace misbehavior (Everton, Jolton, \& Mastrangelo, 2007). The necessity of fairness and justice perceptions 
is central to the human condition at work (Johnston, Krings, Maggiori, Meier, \& Fiori, 2016), and there is strong and persistent meta-analytic substantiation of the fundamental importance of justice as a critical antecedent of job satisfaction and performance (Cohen-Charash \& Spector, 2001; Colquitt, Conlon, Wesson, Porter, \& Ng, 2001; Viswesvaran \& Ones, 2004).

In articulating our focus we did not wish to omit the consideration of individual differences, as these are important considerations in the overall network of behavior at work (Colquitt, et al., 2009; Yau \& Sculli, 1990) Therefore, we included emotional intelligence in our model, which has been shown to be a critical antecedent to work outcomes (Burnett, Williamson \& Bartol, 2009; Kashif, Braganca, Awang, \& De Run, 2017; Lam, Schaubroeck \& Aryee, 2002). The model we tested in this research is thus articulated in Figure 1, and includes two central attitudes - organizational justice and job satisfaction - and three critical personal states of LMX, work motivation, and emotional exhaustion. To be comprehensive of outcomes as well as individual differences we also included the constructs of workplace misbehavior and emotional intelligence. Thus, we arrived at a parsimonious model of central work attitudes and personal states linked to established social psychological theories that have been strongly supported in the work psychology literature.

Accordingly, we now articulate the importance of three critical constructs - job satisfaction, perceived organizational justice, and leader-member exchange (LMX) - as pivotal constructs within the model. In addition, we highlight research pertinent to the related constructs within our proposed model: emotional exhaustion, work motivation, workplace misbehavior, and emotional intelligence.

\subsection{Leader-Member Exchange (LMX)}

The theory of leader-member exchange contends that in dyadic relationships managers tend use diverse styles of management for every subordinate (Graen \& Uhl-Bien, 1995; Waismel-Manor, Tziner, Berger, \& Dikstein, 2010). In turn, each relationship or management style provokes different attitudes in subordinates, which drives the latter to behave differently from each other (Ilies, Nahrgang, \& Morgeson, 2007). Capitalizing on reciprocity theory (Gouldner, 1960) and social exchange theory (SET) (Blau, 1986), employees in good (or bad) relationships with their manager (i.e., high or low LMX) feel compelled/disinclined to reciprocate these relations (see also Adams, 1965).

High- or low-quality LMX produces high or low levels of commitment, trust, and respect. Subordinates with high (or low) LMX relations are likely to receive more (fewer) rewards (formal and informal), resources and career opportunities, and more, or less, support (including emotional) and feedback (Clarke \& Mahadi, 2017; Graen \& Uhl-Bien, 1995). This leads employees to express more positive (negative) behavior (Breevaart, Bakker, Demerouti, \& Van den Heuvel, 2015; Tziner, Fein, Sharoni, Bar-Hen, \& Nord, 2010; Rockstuhl, Dulebohn, Ang, \& Shore, 2012 provide a meta-analysis). It is important to note that, in particular, a bad relationship (i.e., low LMX) with a manager will almost certainly cause mutually "bad" (e.g., counterproductive) behavior (Chernyak-Hai \& Tziner, 2014).

Thus, LMX is one of the integral components of the social network in the work environment (Cole, Schaninger, \& Harris, 2002), and highlights the significant role of managers in motivating employees' performance by providing them with support in addition to other resources (Hobfoll, 1989; Zagenczyk, Purvis, Shoss, Scott, \& Cruz, 2015), which ultimately reduces their physical and emotional exhaustion-the core elements of work burnout (e.g., Huang, Chan, Lam, \& Nan, 2010).

Despite the extensive research on LMX, to the best of our knowledge, while LMX's role as a potential mediator of workplace misbehaviors has been investigated (see, for example, He, Fehr, Yam, Long, \& Hao, 2017; Marstand, Martin, \& Epitropaki, 2017), most studies emphasize contextual-level or job-level predictors (e.g., He et al., 2017; Marstand et al., 2017; Sharif \& Scandura, 2017), and less is known about the effects of individuals' dispositional differences (e.g., Maslyn, Schyns, \& Farmer, 2017). In addition, there is even less emphasis on the effects of demographic and cultural parameters on leader-member interrelations (for further reading, see Zagenczyk et al., 2015).

\subsection{Job Satisfaction}

Job satisfaction is defined as the positive emotional state arising from the overall evaluation of one's job or job experiences, and is related to the degree that one's needs are met in the work environment (Tziner et al., 2012). Consequently, job satisfaction can be both extrinsic, resulting from externally mediated rewards such as satisfactory and appropriate compensation, and intrinsic, originating from internally mediated rewards such as the job itself (Porter and Kramer, 2004). Satisfaction with one's job is also associated with perceptions of organizational justice (Pignata, Winefield, Provis, \& Boyd, 2016). 
Moreover, it has been shown that increased job satisfaction is associated with individual characteristics such as personal traits or temperament (Tziner et al., 2008). For example, attachment-employee psychological commitment and identification with the group - might also be an individual characteristic likely associated with job satisfaction (Bennett \& Robinson, 2003).

\subsection{Perceived Organizational Justice}

In this study, an important antecedent variable is perceived organizational justice, which is defined as the degree to which employees think or feel they are provided with treatment that is apposite, just and respectful, sufficient and accurate information, and rewards and resources (Ambrose \& Schminke, 2009; Cohen-Charash \& Spector, 2001; Colquitt, Conlon, Wesson, Porter, \& Ng, 2001). Hollensbe, Khazanchi and Masterson (2008) assert that these perceptions are a product of personal evaluations based on specific "organizational components," such as leaders and co-workers, and overall impressions based on the consequences of random organizational occurrences.

Typically, organizational justice comprises (1) distributive justice; (2) interactive justice; and (3) procedural justice (see Cohen-Charash \& Spector, 2001; Colquitt et al., 2001; and Niehoff \& Moorman, 1993 for further reading). However, for conciseness, in this study we have confined our exploration to the overall perception of justice. Organizational justice has been researched in detail in the past, but most studies have emphasized its role as a predictor of work outcomes and not as a possible outcome in its own right (e.g., Brienza \& Bobocel, 2017; Shkoler \& Tziner, 2017). Hence, we elected to designate organizational justice as an antecedent to job satisfaction, motivation, and emotional exhaustion, and also as a covariate to emotional intelligence.

Consistent with both social exchange theory (SET) (Blau, 1986) and equity theory (Adams, 1965), when employees feel they are treated justly in their organization they will experience a balanced relationship with the organization and manager. They will likely feel compelled to reciprocate by investing higher levels of energy, time, creativity, and work intensity behaviors (Pan, Chen, Hao, \& Bi, 2018) - in other words, they have high work motivation (Tziner, Fein, \& Oren, 2012). High work motivation leads to the attainment of work goals, followed by appropriate rewards, leading in turn to job satisfaction. Concurrently, as outlined in the section on LMX above, perceived organizational justice enhances high-quality LMX, resulting in augmented levels of commitment, trust and respect. And, of course, the reverse applies with regard to perceived organizational injustice and low-quality LMX.

\subsection{Burnout and Emotional Exhaustion}

According to Maslach (2003), burnout is a progressive psychological response to chronic work stress and is a multidimensional construct that involves three distinct but interrelated aspects: (1) depersonalization (negative attitudes and feelings toward the organization and service recipients); (2) emotional exhaustion; and (3) reduction of personal accomplishment and in the perceived ability to perform effectively. Physical fatigue may also be added to these dimensions of burnout (Shirom and Melamed, 2006).

Burnout can negatively affect employees' state of health. For example, burnout may precipitate hyperlipidemia (Shirom, Toker, Melamed, Berliner, \& Shapira, 2013); exacerbate the risk of type 2 diabetes; and increase the incidence of coronary heart disease (Melamed, Shirom, Toker, \& Shapira, 2006). Toker and Biron, 2012 have also found that burnout is also correlated with depression, and it is an important component of general health outcomes related to total work hours and work-life conflict (Fein \& Skinner, 2015).

Burnout also has organizational implications, such as its impact on effectiveness and performance, and negative attitudes toward work and the organization (Halbesleben \& Bowler, 2007; Maslach, Schaufeli, \& Leiter, 2001). As it intensifies, it has been shown that burnout results in reduced satisfaction with work and, in turn, levels of employee turnover (Baeriswyl, Krause, \& Schwaninger, 2016; Cropanzano, Rupp, \& Byrne, 2003; Moreno-Jimenez et al., 2012; Urien Angulo \& Osca, 2012). Employees with burnout may also negatively impact on co-workers (Bakker, Le Blanc, and Schaufeli, 2005); and burned-out managers may exhaust the whole work environment (Pines \& Aronson, 1988).

Conservation of resources (COR) theory, on which the definition of burnout is based, emphasizes the importance of personal resources in explaining the stress process (Hobfoll, 1989). This theory assumes that individuals are motivated to achieve, preserve, protect, and nurture the things they value - that is, resources (e.g., occupational stability, work satisfaction, self-confidence, loyalty of friends and family, money, property, etc.). Psychological stress occurs when the individual experiences loss of or threat to these resources, or when investment of resources does not produce further expected resources. Burnout transpires when resource depletion becomes chronic. 
In the current study, of the three dimensions comprising burnout, we opted to survey only emotional exhaustion as, reportedly, in two recent meta-analyses, it emerged as the most closely related to antecedents and outcomes of burnout (Cieslak et al., 2014; Lee, Lim, Yang, \& Min Lee, 2011).

\subsection{Perceived Organizational Justice and Burnout}

The negative effects of perceived injustice on burnout have been highlighted in many studies (e.g., Brotheridge, 2003; Liljegren \& Ekberg, 2009; Moliner, Martinez-Tur, Peiro, Ramos, \& Cropanzano, 2005; Son, Kim, \& Kim, 2014). Nevertheless, they have not been thoroughly examined, even in Colquitt et al.'s (2001) meta-analytic review of organizational justice studies. In addition, not all the above studies examined all aspects of organizational justice and/or burnout, and the theoretical justification for connecting the two concepts has been unclear. Nonetheless, despite the paucity of research on the burnout-organizational justice linkage, Hobfoll's (1989) COR theory may provide adequate clarification.

According to COR theory, an individual aspires to acquire and safeguard resources, both social (e.g., intimacy, tenure) and personal (e.g., expertise, self-esteem). He or she might undergo psychological stress if there was (1) a risk of losing resources; (2) actual loss; or (3) a small return on a large initial investment of resources. Resources may personal characteristics (e.g., personality, endurance), personal circumstances (e.g., marriage, work), physical objects, or energies (e.g., time, money), all of which can be quantified and may be used to achieve other goals or resources. We posit that states of organizational injustice would be interpreted as signaling a resource deficit.

As a loss of resources can be seen as threatening, individuals may act to minimize their loss, and those with weaker strategies to deal with stress will also be inclined to develop (sometimes maladaptive) mechanisms of coping. This might include substituting one resource for another (e.g., hasty remarriage after divorce), investing in or using other resources (e.g., working overtime), changing the focus of attention (seeing a threat as a challenge), and re-evaluating resources. It is notable, however, that the ensuant overload caused by investing in these additional resources could result in greater stress and, finally, burnout (Tepper, 2001; Wright \& Cropanzano, 1998). Maslach, Schaufeli and Leiter's (2001) model that focuses on the level of match (or mismatch) between an individual and six areas of their work environment (workload, community, control, fairness, reward, and values), fairness in particular, parallels this finding.

\subsection{Work Motivation}

Another variable we investigated regarding the predictor-outcome relationship is work motivation, that is, the psychological impetus that creates complex cycles of goal-directed thought and behavior (Tziner, et al., 2012). Motivation is what stimulates us to persevere in courses of action until they are accomplished. Hence, scholars of work motivation endeavor to reveal the processes by which an individual's internal, psychological forces - in conjunction with external, environmental forces-impel the persistence, intensity, and direction of personal behavior towards attainment of a goal (Kanfer, Frese, \& Johnson, 2017). Nontheless, Pinder (2014, p. 11) provides another, and currently the most accepted, working definition of work motivation: "Work motivation is a set of energetic forces that originate both within individuals, as well as beyond an individual's being, to initiate work-related behavior and to determine its form, direction, intensity, and duration." Work motivation, then, arises from the synergy between the external environment (societal and organizational) and an individual's characteristics. (Latham \& Pinder, 2005). Research suggests that although personal characteristics may have less weight in determining motivation compared to rewards in the external environment, they are still critical components of determining the worth of outcomes and are always active in determining motivation (Fein \& Klein, 2011; Klein \& Fein 2005). To summarize, motivation might be viewed as the impetus that drives an individual to engage in an activity, and we illustrate the perceptions of organizational justice as an individual antecedent to motivation in the present model.

\subsection{Workplace Misbehavior}

In recent years, workplace misbehaviors (Berry et al., 2007; Bodankin \& Tziner, 2009; Cohen-Charash \& Mueller, 2007; Dilchert, Ones, Davis, \& Rostow, 2007; Levy \& Tziner, 2011) and counterproductive work behaviors (Cohen-Charash \& Mueller, 2007; Ho, 2012; Levine, 2010) have received much attention in the literature, due to their significant economical, sociological, and psychological implications in the work environment (Aubé, Rousseau, Mama, \& Morin, 2009; Bodankin \& Tziner, 2009). These dysfunctional behaviors include withdrawal, harassment, and even theft or sabotage (Bennett \& Robinson, 2000; Spector, Fox, Penney, Bruursema, Goh, \& Kessler, 2006). Important organizational norms are almost invariably violated by these behaviors and organizations' goals, goals, procedures, productivity, profitability, and, of course, employees, are harmed (Aubé et al., 2009; Spector et al., 2006; Vardi \& Weitz, 2002). These behaviors, which may be 
directed toward the whole organization or its members, are costly to both (Bennett \& Robinson, 2003). Work misbehaviors include employees' diminishing their input to 'rectify' the input-outcome imbalance (Greenberg \& Scott, 1996); feeling negatively towards the organization; becoming less motivatied; exhibiting distrust (toward to the workplace and/or the manager); and even acting against the organization (Skarlicki \& Folger, 1997). Hence, work misbehavior is hypothesized as negatively associated with job satisfaction.

Chernyak-Hai and Tziner (2014) showed that the organizational justice-work misbehavior (WMB) relationship existed only when moderated by the degree of leader-member exchange. Nevertheless, the present study will view this organizational justice-WMB association from an different perspective. Namely, that perceptions of injustice can threaten employees' resources, thus leading them to believe they are being inappropriately rewarded for their investment of personal resources. This will lower their work motivation. If it persists, employees will experience frustration. As documented in the literature (Chernyak-Hai \& Tziner, 2014), if employees experience antipathy and imbalance (due, in this instance, to perceived injustice), it is likely that they will seek to regain and preserve balance (Adams, 1965), by which, according to the logic of social exchange theory (SET) (Blau, 1986), work misbehaviors seem a reasonable measure to achieve that balance ("quid pro quo")

\subsection{Emotional Intelligence, Burnout, and $W M B$}

Research (e.g., Bowling \& Eschleman, 2010; Fox, Spector, \& Miles, 2001; Penney \& Spector, 2002, 2005) has also observed the interaction between organizational stressors, WMBs, and personal traits. For instance, emotional intelligence (EI) is a significant personal factor in the success and productivity of organizations (e.g., Newman, Joseph, \& MacCann, 2010) and the regulation of the emotions helps employees to maintain a positive outlook that favorably effects work behaviors_- "positive affect" (Newman et al., 2010) and to restrict "negative affect" (Cheung \& Tang, 2012). High-EI individuals experience less stress at work and more control, job satisfaction, and work commitment (Petrides \& Furnham, 2006), are less prone to emotional fatigue and burnout, and more likely to execute their jobs successfully (Huang et al., 2010). In turn, high-EI employees are less likely turn to work misbehaviors in the face of injustice or burnout. They have the ability to regulate their emotions and the tools to deal with difficulties - in other words, their self-control and self-regulation create balance. Hence, we may posit that emotional intelligence helps control frustrations, thereby leading to less work misbehavior. Concurrently, we may predict that emotional intelligence through its control mechanism will reduce burnout. To conclude, the model in Figure 1 summarizes all the predicted relationships between the variables of investigation articulated so far:

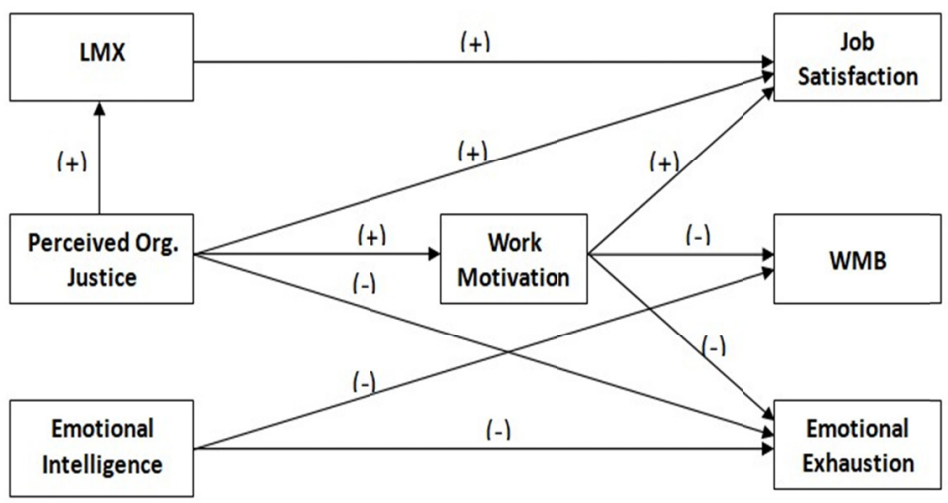

Figure 1. Research model

\section{Method}

\subsection{Participants}

To examine the consistency and replicability of the findings, our data were obtained from a sample of Romanian participants that was split randomly into two sub-samples. The first sub-sample comprised 1,647 participants and the second comprised 1,646 participants. All participants were employees from diverse organizations (high-tech, communications, and telemarketing among others). Table 1 incorporates the demographic information for both sub-samples. 
Table 1. Demographic information for both samples' participants

\begin{tabular}{|c|c|c|c|}
\hline Parameter & Category & $\begin{array}{l}\text { Sample } 1(n=1647) \\
(\%)\end{array}$ & $\begin{array}{l}\text { Sample } 2(n=1646) \\
(\%)\end{array}$ \\
\hline \multirow{2}{*}{ Gender } & Males & 58.3 & 61.7 \\
\hline & Females & 47.1 & 38.3 \\
\hline \multirow[t]{5}{*}{ Age } & $18-25$ & 52.8 & 54.5 \\
\hline & $26-35$ & 23.9 & 22.5 \\
\hline & $36-45$ & 13.0 & 11.5 \\
\hline & $46+$ & 10.3 & 11.5 \\
\hline & High-school & 31.3 & 31.1 \\
\hline \multirow{5}{*}{ Education } & Tertiary & 7.5 & 8.0 \\
\hline & Student/B.A. graduate & 41.8 & 40.9 \\
\hline & Student/M.A. graduate and above & 19.4 & 20.0 \\
\hline & $0-5$ & 65.3 & 67.0 \\
\hline & $5-10$ & 14.7 & 14.4 \\
\hline \multirow{4}{*}{ Tenure } & $10-15$ & 7.6 & 7.4 \\
\hline & $15-20$ & 5.2 & 4.0 \\
\hline & $20-25$ & 3.0 & 2.6 \\
\hline & $25+$ & 4.2 & 4.6 \\
\hline \multirow{2}{*}{ Team work $^{\mathrm{a}}$} & No & 15.1 & 18.0 \\
\hline & Yes & 84.9 & 82.0 \\
\hline \multirow[t]{4}{*}{ Responsibility $^{\mathrm{b}}$} & No & 73.8 & 74.5 \\
\hline & Unit/team manager & 16.6 & 14.8 \\
\hline & Department manager & 6.3 & 7.3 \\
\hline & Director & 3.3 & 3.4 \\
\hline
\end{tabular}

Note. a. Working in a team; b. Responsibility for other people's work.

\subsection{Measures}

Emotional intelligence (EI) was measured using the Trait Emotional Intelligence Questionnaire-Short Form (TEIQue-SF; Petrides \& Furnham, 2003), which includes 30 Likert-type items between 1 ("very little") and 6 ("very much"). Half the items are reverse-scored. In previous studies, the reliability coefficient (Cronbach's $\alpha$ ) of the questionnaire ranged between 0.82 and 0.89 (Cooper \& Petrides, 2010; Petrides \& Furnham, 2006; Pérez, Petrides, \& Furnham, 2005). In the present study, the measure had good reliability: $\alpha=0.92(\mathrm{M}=4.26 ; \mathrm{SD}=$ $0.96)$ for the first sub-sample and $\alpha=0.91(\mathrm{M}=4.25 ; \mathrm{SD}=0.96)$ for the second sub- sample.

Perceived organizational justice (OJ) was measured using the Justice Scale (Niehoff \& Moorman, 1993), which includes 20 Likert-type items between 1 ("completely disagree") and 6 ("completely agree"). The mean reliability coefficient of the questionnaire was 0.84 (Niehoff \& Moorman, 1993). In the current study, the measure had good reliability: $\alpha=0.96(\mathrm{M}=4.13$; $\mathrm{SD}=0.96)$ for the first sub-sample and $\alpha=0.96(\mathrm{M}=4.14$; $\mathrm{SD}=0.95)$ for the second sub-sample.

Burnout was measured using the Maslach Burnout Inventory (MBI; Maslach, Jackson, Leiter, Schaufeli, \& Schwab, 1986). Of the three dimensions of burnout, in this paper we used only emotional exhaustion, comprising nine Likert-type items between 1 ("a few times a year") and 6 ("every day"); for instance, "I feel emotionally drained from my work." In a previous study (Smith \& Tziner, 1998), Cronbach's $\alpha$ of this measure was 0.89. In the current study, the measure had good reliability: $\alpha=0.91(\mathrm{M}=2.74$; $\mathrm{SD}=1.06)$ for the first sub- sample and $\alpha=0.90(\mathrm{M}=2.77 ; \mathrm{SD}=1.06)$ for the second sub-sample. 
Work misbehavior (WMB) was measured by the Interpersonal and Organizational Deviance Scale (IODS; Bennett \& Robinson, 2000), which includes 19 Likert-type items between 1 ("never") and 6 ("every day"); for instance, "I deliberately worked slower than I could." The mean reliability coefficient of the questionnaire was 0.80 (Bennett \& Robinson, 2000). In the current study, the measure had good reliability: $\alpha=0.96$ ( $\mathrm{M}=1.98$; SD $=1.03)$ for the first sub-sample and $\alpha=0.96(\mathrm{M}=1.99 ; \mathrm{SD}=1.02)$ for the second sub-sample.

LMX was gauged by the LMX7 questionnaire (LMX7; Graen \& Uhl-Bien, 1995), consisting of seven Likert-type items; however, each item has a different scale from 1 ("rarely," "not a bit," "not at all," "none," "strongly disagree," "extremely ineffective") to 6 ("very often," "a great deal," "fully," "very high," "strongly agree," "extremely effective"). Original reliability was $\alpha=0.91$. In the current research, reliability was: $\alpha=0.85$ (M = $4.10 ; \mathrm{SD}=0.91)$ for the first sub- sample and $\alpha=0.84(\mathrm{M}=4.12 ; \mathrm{SD}=0.90)$ for the second sub-sample.

Work motivation was gauged by the Work Extrinsic and Intrinsic Motivation Scale (WEIMS; Tremblay, Blanchard, Taylor, Pelletier, \& Villeneuve, 2009), consisting of 18 Likert-type items ranging from 1 ("does not correspond at all") to 6 ("corresponds exactly"); for example, "The reason for being involved in my job is for the satisfaction I experience when I am successful at doing difficult tasks." In the present study, we used the intrinsic dimension of the scale. The measure had high reliability: $\alpha=0.92(\mathrm{M}=4.10 ; \mathrm{SD}=0.86)$ for the first subsample and $\alpha=0.93(\mathrm{M}=4.14 ; \mathrm{SD}=0.87)$ for the second sub-sample.

Job satisfaction was tapped with the MSQ 20-item questionnaire (Weiss, Dawis, England, \& Lofquist, 1967). Each item of the questionnaire assesses a facet of work satisfaction; for instance, "To what extent are you satisfied with the chance to do something that makes use of your abilities?" The responses were given on a 6-point scale. In a previous study (Smith \& Tziner, 1998), the reliability coefficient of this measure was 0.82 . The reliability in this paper was: $\alpha=0.95(\mathrm{M}=4.34 ; \mathrm{SD}=0.89)$ for the first sub-sample and $\alpha=0.95(\mathrm{M}=4.36$; $\mathrm{SD}=0.87)$ for the second sub-sample.

\subsection{Procedure}

The survey (pencil and paper) was given to working people in various organizations to complete voluntarily. After we collected all the data, it was analyzed using the SPSS (v. 22) and AMOS (v. 22) software packages. We assessed Common-method bias (CMB) using harman's single-factor test (Podsakoff, MacKenzie, Lee, \& Podsakoff, 2003) to assess the extent to which intercorrelations among the variables might be an artifact of common method variance (CMV). In order to examine Harman's single-factor test, all variables were loaded on a single factor. This single factor exhibited a poor fit $\left(\chi^{2} /\right.$ d.f. $=67.99, \mathrm{CFI}=0.78, \mathrm{NFI}=0.77, \mathrm{GFI}=0.85$, RMSEA $=0.143$ ), which evidenced that common bias did not pose a serious threat in the current study.

\subsection{Control Variables}

Past empirical research has found no evidence to a meaningful relationship between demographic characteristics and research variables. In this study all correlations between demographic variables presented in Table 1 (age, education, team work, and responsibility) and variable in the model were below 0.1 , therefore, no variables were controlled.

\section{Results}

First, to describe the network of associations among the study's variables, a Pearson correlation matrix was derived, as presented in Table 2 .

Table 2. Correlation matrices for both samples' participants

\begin{tabular}{llllllll}
\hline & $\mathbf{1}$ & $\mathbf{2}$ & $\mathbf{3}$ & $\mathbf{4}$ & $\mathbf{5}$ & $\mathbf{6}$ & $\mathbf{7}$ \\
\hline 1. Perceived Org. Justice & --- & $.58^{* * *}$ & $.21^{* * *}$ & $.47^{* * *}$ & $.77^{* * *}$ & $-.18^{* * *}$ & $-.32^{* * *}$ \\
2. LMX & $.60^{* * *}$ & --- & $.18^{* * *}$ & $.32^{* * *}$ & $.56^{* * *}$ & $-.12^{* * *}$ & $-.27^{* * *}$ \\
3. Emotional Intelligence & $.24^{* * *}$ & $.24^{* * *}$ & --- & $.13^{* * *}$ & $.25^{* * *}$ & $-.52^{* * *}$ & $-.54^{* * *}$ \\
4. Work Motivation & $.48^{* * *}$ & $.32^{* * *}$ & $.13^{* * *}$ & --- & $.60^{* * *}$ & $-.21^{* * *}$ & $-.16^{* * *}$ \\
5. Job Satisfaction & $.76^{* * *}$ & $.60^{* * *}$ & $.28^{* * *}$ & $.56^{* * *}$ & --- & $-.27^{* * *}$ & $-.31^{* * *}$ \\
6. WMB & $-.18^{* * *}$ & $-.14^{* * *}$ & $-.48^{* * *}$ & $-.19^{* * *}$ & $-.29^{* * *}$ & --- & $.31^{* * *}$ \\
7. Emotional Exhaustion & $-.33^{* * *}$ & $-.28^{* * *}$ & $-.53^{* * *}$ & $-.17^{* * *}$ & $-.29^{* * *}$ & $.32^{* * *}$ & --- \\
\hline
\end{tabular}

Notes. ${ }^{* * *} p<.001$. Pearson correlation are shown for Sample 1 (above the diagonal) and Sample 2.

An initial investigation of the results revealed that all correlations between independent variables in the model 
were between 0.13 and 0.60 , thus indicating no issue of multi-collinearity. Still, we conducted a multiple linear regression model to obtain the variance inflation factor (VIF) for all the variables. These are represented in Table 3 along with scale statistics. The VIF values of 1.37 to 3.23 in Table 3 are substantially below the conventional cut-off of 10, which indicates that the independent variables do not have a multi-collinearity problem. Therefore, all variables were retained for structural equation modeling.

Table 3. Descriptive statistics between different two sub-samples

\begin{tabular}{llllllllll}
\hline & & \multicolumn{1}{c}{ Sample 1 $(\boldsymbol{n}=\mathbf{1 6 4 7})$} & \multicolumn{4}{c}{ Sample 2 $(\boldsymbol{n}=\mathbf{1 6 4 6})$} \\
\hline & & M & SD & $\boldsymbol{\alpha}$ & VIF & M & SD & $\boldsymbol{\alpha}$ & VIF \\
\hline 1. & Perceived Org. Justice & 4.13 & 0.96 & 0.96 & 2.69 & 4.14 & 0.95 & 0.96 & 2.65 \\
2. & LMX & 4.10 & 0.91 & 0.85 & 1.67 & 4.12 & 0.90 & 0.84 & 1.71 \\
3. & Emotional Intelligence & 4.26 & 0.96 & 0.92 & 1.75 & 4.25 & 0.96 & 0.91 & 1.64 \\
4. & Work Motivation & 4.10 & 0.86 & 0.92 & 1.57 & 4.14 & 0.87 & 0.93 & 1.48 \\
5. & Job Satisfaction & 4.34 & 0.89 & 0.95 & 3.23 & 4.36 & 0.87 & 0.95 & 3.07 \\
6. & WMB & 1.98 & 1.03 & 0.72 & 1.43 & 1.99 & 1.02 & 0.61 & 1.37 \\
7. & Emotional Exhaustion & 2.74 & 1.06 & 0.91 & 1.49 & 2.77 & 1.06 & 0.90 & 1.52 \\
\hline
\end{tabular}

Notes. $M=$ mean; $S D=$ standard deviation; $\alpha=$ Cronbach's Alpha Coefficient; $V I F=$ variance inflation factor.

In the next step, we employed the use of structural equation modeling (SEM) to capture the multivariate relationships as proposed in our model (see Figure 1). To evaluate the fit of the model, the AMOS software package was used to employ the SEM analysis (Figure 2).

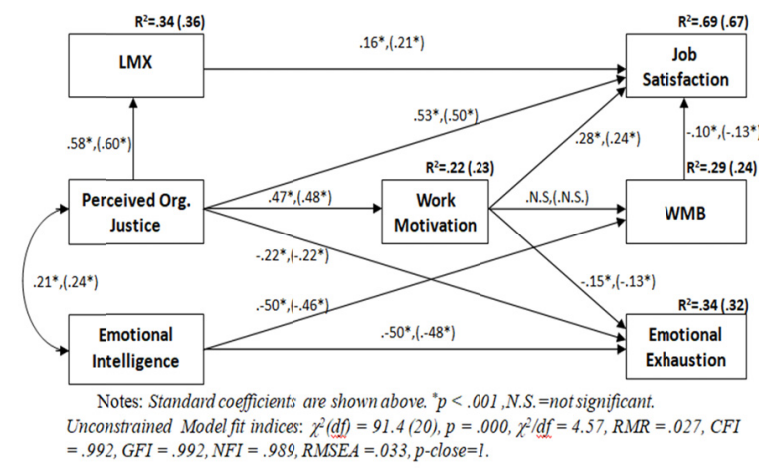

Figure 2. Path diagram for sub- sample $1(\mathrm{n}=1647)$, and sub-sample $2(\mathrm{n}=1646$; in parenthesis)

As indicated in Table 4 and Figure 2, the unconstrained model fit the data in an absollute sense with each fit index $\chi^{2} /$ d.f. (chi-square/degree of freedom) $=4.57$; CFI (comparative-fit-index) $=0.992$; NFI (normed-fit-index) $=0.99 ;$ GFI $($ good-fit-index $)=0.992$; RMSEA (root mean square error of approximation) $=0.033$. As suggested by previous research, all the practical indices were within the fit range $\left(\chi^{2} /\right.$ d.f. $<5, \mathrm{CFI}>.9$, NFI $>.9$, GFI $>.80$, RMSEA<.08) (Kline, 2005).

Comparison between the model with and without the equality constraints on all paths revealed that in the model with the constraints, the chi-square had gone up from 91.4 to 107.2 , and we gained ten degrees of freedom (based on the number of constraints) as portrayed in Table 4.

Table 4. Goodness of fit -statistics for the structural equation modeling comparison

\begin{tabular}{lllllll}
\hline Models & $\chi^{\mathbf{2}}$ (d.f.) & $\chi^{2}$ /d.f. & CFI & NFI & GFI & RMSEA \\
\hline $\begin{array}{l}\text { Unconstrained } \\
\text { Model }\end{array}$ & $91.4(20)$ & 4.57 & 0.992 & 0.989 & 0.992 & 0.033 \\
Constrained Model & $107.2(30)$ & 3.57 & 0.991 & 0.988 & 0.991 & 0.028 \\
\hline
\end{tabular}

Note. imposed across-group equality constraints on all path estimates. 
By calculating the difference in chi-square and degrees of freedom, and using these in a formal chi-test, we found that the chi-square difference was not significant $\left(\Delta \chi^{2}(\mathrm{df})=15.8(10), p=.107\right)$, so we can assume that the constrained model was not significantly different from the unconstrained model; therefore, there is no significant difference between the path parameters across both samples.

We can see also in Figure 2 that perceived organizational justice has a significant positive impact on LMX $(\beta=.58,(.60) ; \mathrm{p}<.001)$, job satisfaction $(\beta=.53,(.50) ; \mathrm{p}<.001)$, work motivation $(\beta=.47,(.48) ; \mathrm{p}<.001)$, and a significant negative impact on emotional exhausting $(\beta=-.22(-.22) ; \mathrm{p}<.001)$. Emotional intelligence has a negative significant impact on WMB $(\beta=-.50(-.46) ; \mathrm{p}<.001)$ and emotional exhaustion $(\beta=-.50(-.48) ; \mathrm{p}<.001)$. LMX has a positive impact on job satisfaction $(\beta=.16(.21) ; \mathrm{p}<.001)$.

Work motivation has a positive significant impact on job satisfaction $(\beta=.28,(.24) ; \mathrm{p}<.001)$ and a negative significant effect on emotional exhaustion $(\beta=-.15(-.13) ; \mathrm{p}<.001)$. Additionally, results of modification indices lead to an unexpected negative significant relationship between WMB and job satisfaction $(\beta=-.10(-.13)$; $\mathrm{p}<0.0 .01$ ). These findings support all our expectations (see Figure 1), except the relationship between work motivation and WMB that was not supported by our findings.

\section{Discussion}

The main finding of this research is that the comprehensive model we presented in Figure 1 is an indeed a reliable and valid tools for educating managers. The model displays a very high level of reliability based on the exceptional fit of the measurement model across both samples, and a high level of validity based on the structural paths embedded in the nomological network, which was supported across both very large sub- samples. Specifically, in this research we tested the measurement model and structural model displayed in Figure 2. We tested this model across two separate sub-samples from the same population to ensure we could not capitalize on error variability when reproducing results. Our results from both sub-samples indicate factorial invariance for the measurement model as well as support for the structural paths. The difference in the constrained versus unconstrained models was non-significant which leads us to conclude that model fits and allows a reliable inference of path estimates. In the analyses from both sub-samples fit was high and the path estimates are stable indicating support for these parameters in the population.

Measurement reliability was a strength of this research, with alpha estimates ranging from $.84-.92$ across both sub- samples with almost all alpha estimates equal or greater than .90 . The median alpha estimates across both sub-samples was .94. When coupled with the very strong indices of fit (e.g. RMESA $<.05$ across both sub-samples) and the very high sample size of (over 1640 participants in both sub-samples) we can conclude that the scales used in this research display very high levels of reliability.

Another major contribution of this research is that organizational justice was associated with about one quarter of the variability in work motivation and over a third of the variability in LMX. The magnitude of the effect size for this single variable is impressive (Cohen, 1992) and the fact that organizational justice holds such a parsimonious role in the model suggests that it should be included as a central construct in studies of associations between LMX, work motivation, and job satisfaction. These links are important because perceptions of organizational justice are also critical to the effective functioning of organizations (Sharoni, Tziner, Fein, Shultz, Shaul, \& Zilberman 2012).

In respect to job satisfaction, our results show that the model accounted for two-thirds of the variance in job satisfaction, which is impressive given the central role of job satisfaction in work and organizational psychology research. Historically, job satisfaction is seen as a critical component of intention and cognition within the turnover process (Colquitt et al., 2009). Although there is able evidence for variables extraneous to our model as determinants of job satisfaction, such as genetic factors (Arvey, McCall, Bouchard, Taubman, \& Cavanaugh, 1994), a model that accounts for two-thirds of the variability in this critical work attitude can be of great practical value to human resource practice and research. For example, applied work on turnover suggests that job satisfaction is an area of the turnover pathway still subject to management control, and can be influenced independent of labor market conditions, largely through the impact of organizational leadership and antecedents to motivation (Colquitt, et al., 2009).

\section{Conclusion}

Further research studies should consider longitudinal designs or experimental designs, which are required to provide strong evidence of causation along the paths in our model. We would recommend that such studies should be expanded to include both group and organizational level constructs such as measures of group cohesion or organizational effectiveness. All of these constructs are important components of the organizational 
context encountered by new managers. We observe that such organizational contexts are complex and additional variability in outcomes will fall outside of the proposed model. However, the model presented in this paper will still serve as a parsimonious tool to explain a large part of the complexity in employee behavior and is backed by the strong empirical research included in this study.

\section{Limitations and Future Research}

We note that the paths illustrated in this research do not provide direct casual evidence. However, they do indicate very strong networks of association that might be leveraged to explain focal constructs in more detail such as unique variance in LMX (Lu, 2016). Another limitation is that we based our measurement in self-report questionnaires. Although we found no evidence of significant common method variance, multiple self-report questionnaires will contain some shared variability due to measurement methods. Finally, we recognize that phenomenon in organizations exist in complex, multi-level networks. Although we have presented a parsimonious model of key variables, the constructs reflected in our research could be expanded to include both group and organizational level constructs such as measures of group cohesion or organizational effectiveness. Future studies might also incorporate a small number of additional variables as covariates - both in terms of states, which could include justice related contextual variables such as illegitimate tasks (Omansky, Eatough, \& Fila, 2016), and in terms of individual differences such as age, which has been shown to moderate the relationship between justice and emotional exhaustion (Brienza \& Bobocel, 2017).

We note the abundance of research supporting the necessity of a model to serve as an advanced organizer as part of guided instruction in complex environments (Kirschner, Sweller, \& Clark, 2012; Mayer, 2004). When embarking on management development programs, the model presented in this paper could serve as a central component of guided instruction for new managers. To examine the determinants of organizational justice in more detail, we recommend that managers use interview data, which might include performance management conversations as well as exit interview data that could provide a retrospective account of justice perceptions. As part of such studies we would recommend the use of multi-level modelling methods to further investigate the team level variables in organizational contexts. This would be particularly important for our proposed model because over $80 \%$ of participants in both sub-samples worked in teams.

\section{References}

Abekah-Nkrumah, G., \& Atinga, R. A. (2013). Exploring the link between organizational justice and job satisfaction and performance in Ghanaian hospitals. International Journal of Workplace Health Management, 6(3), 189-204. https://doi.org/10.1108/IJWHM-04-2011-0011

Adams, J. S. (1965). Inequity in social exchange. In L. Berkowitz (Ed.), Advances in experimental social psychology (Vol. 2, pp. 267-299). New York, NY: Academic Press.

Ambrose, M. L., \& Schminke, M. (2009). The role of overall justice judgments in organizational justice research. Journal of Applied Psychology, 94, 491-500. https://doi.org/10.1037/a0013203

Aquino, K., Galperin, B. L., \& Bennett, R. J. (2004). Social status and aggressiveness as moderators of the relationship between interactional justice and workplace deviance. Journal of Applied Social Psychology, 34(5), 1001-1029. https://doi.org/10.1111/j.1559-1816.2004.tb02581.x

Arvey, R. D., McCall, B. P., Bouchard Jr, T. J., Taubman, P., \& Cavanaugh, M. A. (1994). Genetic influences on job satisfaction and work values. Personality and Individual Differences, 17(1), 21-33. https://doi.org/10.1016/j.obhdp.2011.08.005

Aubé, C., Rousseau, V., Mama, C., \& Morin, E. (2009). Counterproductive behaviors and psychological well-being: The moderating effect of task interdependence. Journal of Business and Psychology, 24, 351-361. https://doi.org/10.1007/s10869-009-9113-5

Baeriswyl S, K. A., \& Schwaninger, A. (2016). Emotional Exhaustion and Job Satisfaction in Airport Security Officers - Work-Family Conflict as Mediator in the Job Demands-Resources Model. Frontiers in Psychology, 7, 663. https://doi.org/10.3389/fpsyg.2016.00663

Bakker, A. B., LeBlanc, P. M., \& Schaufeli, W. B. (2000). A multilevel analysis of burnout contagion effects among nurses who work at intensive care units. Journal of Advanced Nursing 51(3), 276-287. https://doi.org/10.1111/j.1365-2648.2005.03494.x

Bennett, R. J., \& Robinson, S. L. (2000). Development of a measure of workplace deviance. Journal of Applied Psychology, 85, 349-360. https://doi.org/10.I037//0021-9010.85.3.349 
Bensemmane, S., Ohana, M., \& Stinglhamber, F. (2018). Team justice and thriving: a dynamic approach. Journal of Managerial Psychology, 33(2), 229-242. https://doi.org/10.1108/JMP-07-2017-0223

Bernerth, J., \& Walker, H. J. (2012). Reexamining the workplace justice to outcome relationship: does frame of reference matter? Journal of Management Studies, 49(5), 945-969. https://doi.org10.1111/j.1467-6486.2010.00977.x

Berry, C. M., Ones, D. S., \& Sackett, P. R. (2007). Interpersonal deviance, organizational deviance, and their common correlates: A review and meta-analysis. Journal of Applied Psychology, 92(2), 410-424. https://doi.org/10.1037/0021-9010.92.2.410

Biswas, S., \& Kapil, K. (2017). Linking perceived organizational support and organizational justice to employees' in-role performance and organizational cynicism through organizational trust: A field investigation in India. Journal of Management Development, 36(5), 696-711. https://doi.org/10.1108/JMD-04-2016-0052

Blau, P. (1986). Exchange and Power in Social Life (2nd ed.). New York: Routledge.

Bodankin, M., \& Tziner, A. (2009). Constructive deviance, destructive deviance and personality: how do they interrelate? Amphiteatru Economic Journal, 11, 549-564.

Bowling, N. A., \& Eschleman, K. J. (2010). Employee personality as a moderator of the relationships between work stressors and counterproductive work behavior. Journal of occupational health psychology, 15(1), 91. https://doi.org/10.1037/a0017326 .

Brienza, J. P., \& Bobocel, D. R. (2017). Employee age alters the effects of justice on emotional exhaustion and organizational deviance. Frontiers in psychology, 8, 479. https://doi.org/10.3389/fpsyg.2017.00479

Brotheridge, C. M. (2003). The Role of Fairness in Mediating the Effects of Voice and Justification on Stress and Other Outcomes in a Climate of Organizational Change. International Journal of Stress Management, 10(3), 253. https://doi.org/10.1037/1072-5245.10.3.253

Burnett, M., Williamson, I., \& Bartol, K. (2009). The Moderating Effect of Personality on Employees' Reactions to Procedural Fairness and Outcome Favorability. Journal of Business \& Psychology, 24(4), 469-484. https://doi.org/10.1007/s10869-009-9120-6

Chernyak-Hai, L., \& Tziner, A. (2014). Relationships between counterproductive work behavior, perceived justice and climate, occupational status, and leader-member exchange. Journal of Work and Organizational Psychology, 30, 1-12. https://doi.org/10.5093/tr2014a1

Cheung, F. Y. L., \& Tang, C. S. K. (2012). The effect of emotional dissonance and emotional intelligence on work-family interference. Canadian Journal of Behavioural Science/Revue canadienne des sciences du comportement, 44(1), 50. https://doi.org/10.1037/a0025798

Choy, J., McCormack, D., Djurkovic, N. (2016). Leader-member exchange and job performance: The mediating roles of delegation and participation. Journal of Management Development, 35(1), 104-119. https://doi.org/10.1108/JMD-06-2015-0086

Cieslak, R., Shoji, K., Douglas, A., Melville, E., Luszczynska, A., \& Benight, C. C. (2014). A meta-analysis of the relationship between job burnout and secondary traumatic stress among workers with indirect exposure to trauma. Psychological Services, 11(1), 75. https://doi.org/10.1037/a0033798.

Clarke, N., \& Mahadi, N. (2017). Differences between follower and dyadic measures of LMX as mediators of emotional intelligence and employee performance, well-being, and turnover intention. European Journal of Work and Organizational Psychology, 26(3), 373-384, https://doi.org/10.1080/1359432X.2016.1263185

Clay-Warner, J., Reynolds, J., \& Roman, P. (2005). Organizational Justice and Job Satisfaction: A Test of Three Competing Models. Social Justice Research, 18(4), 391-409. https://doi.org/10.1007/s11211-005-8567-5

Cohen, J. (1992). A power primer. Psychological bulletin, 112(1), 155. https://doi.org/10.1037//0033-2909.112.1.155

Cohen-Charash, Y., \& Mueller, J. S. (2007). Does perceived unfairness exacerbate or mitigate interpersonal counterproductive work behaviors related to envy? Journal of applied psychology, 92(3), 666-680. https://doi.org/10.1037/0021-9010.92.3.666 
Cohen-Charash, Y., \& Spector, P. E. (2001). The role of justice in organizations: a meta-analysis. Organizational Behavior and Human Decision Processes, 86(2), 278-321. https://doi.org/10.1006/obhd.2001.2958

Cole, M. S., Bernerth, J. B., Walter, F., \& Holt, D. T. (2010). Organizational justice and individuals' withdrawal: unlocking the influence of emotional exhaustion. The Journal of Management, 47(3), 367-390. https://doi.org/10.1111/j.1467-6486.2009.00864.x

Cole, M., Schaninger, W., \& Harris, S. (2007). The workplace social network exchange: a multilevel, conceptual examination. Group \& Organization $\quad$ Management, $\quad 27(1), \quad$ 142-167. https://doi.org/10.1177/1059601102027001008

Colquitt, J. A., Conlon, D. E., Wesson, M. J., Porter, C. O. L. H., \& Ng, K. Y. (2001). Justice at the millennium: a meta-analytic review of 25 years of organizational justice research. Journal of Applied Psychology, 86(3), 425-445. https://doi.org/10.1037/0021-9010.86.3.425

Colquitt, J. A., Le Pine, J. A., \& Wesson, M. J. (2009). Organizational Behavior: Improving Performance and Commitment in the workplace. New York: McGraw-Hill Irwin.

Cooper, A., \& Petrides, K. V. (2010). A psychometric analysis of the Trait Emotional Intelligence Questionnaire-Short Form (TEIQue-SF) using item response theory. Journal of personality assessment, 92(5), 449-457. https://doi.org/10.1080/00223891.2010.497426

Dilchert, S., Ones, D. S., Davis, R. D., \& Rostow, C. D. (2007). Cognitive ability predicts objectively measured https://doi.org/10.1037/0021-9010.92.3.616

Dusterhoff, C., Cunningham, J., \& MacGregor, J. (2014). The Effects of Performance Rating, Leader-Member Exchange, Perceived Utility, and Organizational Justice on Performance Appraisal Satisfaction: Applying a Moral Judgment Perspective. https://doi.org/10.1007/s10551-013-1634-1

Elamin, A. M. (2012). Perceived organizational justice and work-related attitudes: a study of Saudi employees. World Journal of Entrepreneurship, Management and Sustainable Development, 8(1), 71-88. https://doi.org/10.5539/mas.v13n2p42

Elanain, H. A. (2010). Testing the direct and indirect relationship between organizational justice and work outcomes in a non-Western context of the UAE. Journal of Management Development, 29(1), 5-27. https://doi.org/10.1108/02621711011009045

Erdogan, B., \& Bauer, T. N. (2010). Differentiated leader-member exchanges: The buffering role of justice climate. Journal of Applied Psychology, 95(6), 1104-1120. https://doi.org/10.1037/a0020578

Erdogan, B., \& Liden, R. C. (2004). Collectivism as a moderator of responses to organizational justice: implications for leader-member exchange and ingratiation. Journal of Organizational Behavior, 27(1), 1-17. https://doi.org/10.1002/job.365

Everton, W. J., Jolton, J. A., \& Mastrangelo, P. M. (2007). Be nice and fair or else: understanding reasons for employees' deviant behaviors. Journal of Management Development, 26(2). https://doi.org/10.1108/02621710710726035

Faragher, E. B., Cass, M., \& Cooper, C. L. (2013). The relationship between job satisfaction and health: a meta-analysis. In From Stress to Wellbeing (Volume 1, pp. 254-271). P London: algrave Macmillan.

Fein, E. C., \& Skinner, N. (2015). Clarifying the effect of work hours on health through work-life conflict. Asia Pacific Journal of Human Resources, 53, 448-470. https://doi.org/10.1111/1744-7941.12065

Fein, E. C., Tziner, A., Lusky, L., \& Palachy, O. (2013). Relationships between ethical climate, justice perceptions, and LMX. Leadership \& Organization Development Journal, 34(2), 147-163. https://doi.org/10.1108/01437731311321913

Flaherty, S., \& Moss, S. A. (2007). The Impact of Personality and Team Context on the Relationship between Workplace Injustice and Counterproductive Work Behavior. Journal of Applied Social Psychology, 37(11), 2549-2575. https://doi.org/10.1111/j.1559-1816.2007.00270.x

Fortin, M., Cojuharenco, I., P atient, D., \& German, H. (2016). It is time for justice: How time changes what we know about justice judgments and justice effects. Journal of Organizational Behavior, 37(Suppl 1), S30-S56. https://doi.org/10.1002/job.1958 
Ghosh, P., Rai, A., \& Sinha, A. (2014). Organizational justice and employee engagement: Exploring the linkage in public sector banks in India. Personnel Review, 43(4), 628-652. https://doi.org/10.1108/PR-08-2013-0148

Gouldner A W. (1960). The norm of reciprocity: a preliminary statement. American Sociological Review, 25, 161-78. https://doi.org/10.2307/2092623

Graen, G. B., \& Uhl-Bien, M. (1995). Relationship-based approach to leadership: Development of leadermember exchange (LMX) theory of leadership over 25 years: Applying a multi-level multi-domain perspective. Leadership Quarterly, 6, 219-247.

Haar, J. M., \& Spell, C. S. (2009). How does distributive justice affect work attitudes? The moderating effects of autonomy. International Journal of Human Resource Management, 20(8), 1827-1842. https://doi.org/10.1080/09585190903087248

Halbesleben, J. R., \& Bowler, W. M. (2007). Emotional exhaustion and job performance: the mediating role of motivation. Journal of applied psychology, 92(1), 93. https://doi.org/10.1037/0021-9010.92.1.93

Hausknecht, J. P., Sturman, M. C., \& Roberson, Q. M. (2011). Justice as a dynamic construct: Effects of individual trajectories on distal work outcomes. Journal of Applied Psychology, 96(4), 872-880. https://doi.org/10.1037/a0022991

He, W., Fehr, R., Yam, K. C., Long, L. R., \& Hao, P. (2017). Interactional justice, leader-member exchange, and employee performance: Examining the moderating role of justice differentiation. Journal of Organizational Behavior, 38(4), 537-557. https://doi.org/10.1002/job.2133

Ho, V. T. (2012). Interpersonal Counterproductive Work Behaviors: Distinguishing Between Person-Focused Versus Task-Focused Behaviors and Their Antecedents. Journal of Business and Psychology, 27, 467-482. https://doi.org/10.1007/s10869-012-9256-7

Hobfoll, S. E. (1989). Conservation of resources: A new attempt at conceptualizing stress. American psychologist, 44(3), 513.

Hollensbe, E. C., Khazanchi, S., \& Masterson, S. S. (2008). How do I assess if my supervisor and organization are fair? Identifying the rules underlying entity-based justice perceptions. Academy of Management Journal, 51(6), 1099-1116. https://doi.org/10.5465/AMJ.2008.35732600

Huang, X., Chan, S. C., Lam, W., \& Nan, X. (2010). The joint effect of leader-member exchange and emotional intelligence on burnout and work performance in call centers in China. The International Journal of Human Resource Management, 21(7), 1124-1144. https://doi.org/10.1080/09585191003783553

Hunt, J. W. (1982). Developing Middle Managers in Shrinking Organizations. Journal of Management Development, 1(2).

Iaffaldano, M. T., \& Muchinsky, P. M. (1985). Job satisfaction and job performance: A meta-analysis. Psychological bulletin, 97(2), 251.

Ilies, R., Nahrgang, J. D., \& Morgeson, F. O. (2007). Leader-member exchange and citizenship behaviors: A meta-analysis. Journal of Applied Psychology, 92, 269-277. https://doi.org/10.1037/0021-9010.92.1.269

Johnston, C. S., Krings, F., Maggiori, C., Meier, L. L., \& Fiori, M. (2016). Believing in a personal just world helps maintain well-being at work by coloring organizational justice perceptions. European Journal of Work \& Organizational Psychology, 25(6), 945-959. https://doi.org/10.1080/1359432X.2016.1192132

Kanfer, R., Frese, M., \& Johnson, R. E. (2017). Motivation related to work: A century of progress. Journal of Applied Psychology, 102(3), 338.

Kashif, M., Braganca, E, Awang, Z., \& De Run, E. C. (2017). You abuse but I will stay: The combined effects of job stress, customer abuse, and emotional intelligence on employee turnover. Journal of Management Development, 36(7).

Kernan, M., \& Hanges, P. (2002). Survivor reactions to reorganization: Antecedents and consequences of procedural, interpersonal, and informational justice. Journal of Applied Psychology, 87, 916-928.

Kirschner, P. A., Sweller, J., \& Clark, R. E., (2006) Why Minimal Guidance During Instruction Does Not Work: An Analysis of the Failure of Constructivist, Discovery, Problem-Based, Experiential, and Inquiry-Based Teaching. Educational Psychologist, 41(2), 75-86. https://doi.org/10.1207/s15326985ep4102_1 
Klein, H. J., \& Fein, E. C. (2005). Goal propensity: Understanding and predicting individual differences in motivation. Research in personnel and human resources management, 215-263.

Lam, S. K., Schaubroeck, J., \& Aryee, S. (2002). Relationship between organizational justice and employee work outcomes: a cross-national study. Journal of Organizational Behavior, 23(1), 1-18. https://doi.org/10.1002/job.131

Lamertz, K. (2002). The social construction of fairness: Social influence and sense making in organizations. Journal of Organizational Behavior, 23(1), 19-37. https://doi.org/10.1002/job.128

Latham, G. P., \& Pinder, C. C. (2005). Work motivation theory and research at the dawn of the twenty-first century. Annu. Rev. Psychol., 56, 485-516.

Lee, J., Lim, N., Yang, E., \& Lee, S. M. (2011). Antecedents and consequences of three dimensions of burnout in psychotherapists: A meta-analysis. Professional Psychology: Research and Practice, 42(3), 252.

Leiter, M. P., Gascón, S., \& Martínez-Jarreta, B. (2010). Making Sense of Work Life: A Structural Model of Burnout. Journal of Applied Social Psychology, 40(1), 57-75. https://doi.org/10.1111/j.1559-1816.2009.00563.x

Leung, K., Wang, Z., \& Smith, P. B. (2001). Job attitudes and organizational justice in joint venture hotels in China: the role of expatriate managers. International Journal of Human Resource Management, 12(6), 926-945. https://doi.org/10.1080/09585190110063165

Levine, E. L. (2010). Emotion and power (as a social influence): Their impact on organizational citizenship and counterproductive individual and organizational behavior. Human Resource Management Review, 20, 4-17.

Levy, T., \& Tziner, A. (2011). When destructive deviance in the workplace becomes a liability: A decisional behavioral model. Quality and Quantity, 45, 233-239.

Liljegren, M., \& Ekberg, K. (2009). The associations between perceived distributive, procedural, and interactional organizational justice, self-rated health and burnout. Work, 33(1), 43-51.

Marstand, A. F., Martin, R., \& Epitropaki, O. (2017). Complementary person-supervisor fit: An investigation of supplies-values (SV) fit, leader-member exchange (LMX) and work outcomes. The Leadership Quarterly, $28(3), 418-437$.

Maslach, C. (2003). Burnout: The cost of caring. Ishk.

Maslach, C., Jackson, S. E., Leiter, M. P., Schaufeli, W. B., \& Schwab, R. L. (1986). Maslach burnout inventory (Vol. 21, pp. 3463-3464). Palo Alto, CA: Consulting Psychologists Press.

Maslyn, J. M., Schyns, B., \& Farmer, S. M. (2017). Attachment style and leader-member exchange: the role of effort to build high quality relationships. Leadership \& Organization Development Journal, 38(3), 450-462.

Matta, F. K., Erol-Korkmaz, H. T., Johnson, R. E., \& Biçaksiz, P. (2014). Significant work events and counterproductive work behavior: The role of fairness, emotions, and emotion regulation. Journal of Organizational Behavior, 35(7), 920-944. https://doi.org/10.1002/job.1934

Mayer, D. M., Bardes, M., \& Piccolo, R. F. (2008). Do servant-leaders help satisfy follower needs? An organizational justice perspective. European Journal Of Work \& Organizational Psychology, 17(2), 180-197. doi:10.1080/13594320701743558

Mayer, R. E. (2004). Should There Be a Three-Strikes Rule Against Pure Discovery Learning? The Case for Guided Methods of Instruction. American Psychologist, 59(1), 14-19. https://doi.org/10.1037/0003-066X.59.1.14

McCarthy, G., \& Milner, J. (2013). Managerial coaching: challenges, opportunities and training. Journal of Management Development, 32(7).

Melamed, S., Shirom, A., Toker, S., Berliner, S., \& Shapira, I. (2006). Burnout and risk of cardiovascular disease: Evidence, possible causal paths, and promising research directions. Psychological bulletin, 132(3), 327.

Milner, J., McCarthy, G., \& Milner t. (2018). Training for the coaching leader: how organizations can support managers. Journal of Management Development, 37(2).

Moliner, C., Martínez-Tur, V., Peiró, J. M., Ramos, J., \& Cropanzano, R. (2005). Relationships between organizational justice and burnout at the work-unit level. International Journal of Stress Management, 12(2), 99 . 
Nadiri, H., \& Tanova, C. (2010). An investigation of the role of justice in turnover intentions, job satisfaction, and organizational citizenship behavior in hospitality industry. International Journal of Hospitality Management, 29(1), 33-41.

Newman, D. A., Joseph, D. L., \& MacCann, C. (2010). Emotional intelligence and job performance: The importance of emotion regulation and emotional labor context. Industrial and Organizational Psychology, $3(2), 159-164$.

Niehoff, B. P., \& Moorman, R. H. (1993). Justice as a mediator of the relationship between methods of monitoring and organizational citizenship behavior. Academy of Management Journal, 36, 527-556.

Omansky R, Eatough EM \& Fila MJ (2016) Illegitimate Tasks as an Impediment to Job Satisfaction and Intrinsic Motivation: Moderated Mediation Effects of Gender and Effort-Reward Imbalance. Frontiers in Psychology, 7, 1818. https://doi.org/10.3389/fpsyg.2016.01818

Ouyang, Z., Sang, J., Li, P., \& Peng, J. (2015). Organizational justice and job insecurity as mediators of the effect of emotional intelligence on job satisfaction: A study from China. Personality \& Individual Differences, 76147-152. https://doi.org/10.1016/j.paid.2014.12.004

Pan, X., Chen, M, Hao, Z., \& Bi W. (2018). The Effects of Organizational Justice on Positive Organizational Behavior: Evidence from a Large-Sample Survey and a Situational Experiment. Frontiers in Psychology, (8), https://doi.org/10.3389/fpsyg.2017.02315

Park, Y., Song, J. H., \& Lim, D. H. (2016). Organizational justice and work engagement: the mediating effect of self-leadership. Leadership \& Organization Development Journal, 37(6), 711-729.

Penney, L. M., \& Spector, P. E. (2005). Job stress, incivility, and counterproductive work behavior (CWB): The moderating role of negative affectivity. Journal of Organizational Behavior: The International Journal of Industrial, Occupational and Organizational Psychology and Behavior, 26(7), 777-796.

Petrides, K. V., \& Furnham, A. (2003). Trait emotional intelligence: Behavioural validation in two studies of emotion recognition and reactivity to mood induction. European journal of personality, 17(1), 39-57.

Petrides, K. V., \& Furnham, A. (2006). The Role of Trait Emotional Intelligence in a Gender-Specific Model of Organizational Variables 1. Journal of Applied Social Psychology, 36(2), 552-569.

Pignata, S., Winefield, A. H., Provis, C., \& Boyd, C. M. (2016). A Longitudinal Study of the Predictors of Perceived Procedural Justice in Australian University Staff. Frontiers in Psychology, 7, 1271. https://doi.org/10.3389/fpsyg.2016.01271

Pinder, C. C. (2014). Work motivation in organizational behavior. Psychology Press.

Pines, A., \& Aronson, E. (1988). Career burnout: Causes and cures. Free press.

Podsakoff, P. M., MacKenzie, S. B., Lee, J. Y., \& Podsakoff, N. P. (2003). Common method biases in behavioral research: A critical review of the literature and recommended remedies. Journal of applied psychology, 88(5), 879.

Poon, J. L. (2012). Distributive justice, procedural justice, affective commitment, and turnover intention: A mediation-moderation framework. Journal of Applied Social Psychology, 42(6), 1505-1532. https://doi.org/10.1111/j.1559-1816.2012.00910.x

Porter, M. E., \& Kramer, M. R. (2004). Strategy and society: The link between competitive advantage and corporate social responsibility. Harvard Business Review, 84, 5-12.

Proost, K., Verboon, P., \& van Ruysseveldt, J. (2015). Organizational justice as buffer against stressful job demands. Journal of Managerial Psychology, 30(4), 487-499. https://doi.org/10.1108/JMP-02-2013-0040

Rast, D. E., Axtell, C., \& McGlynn, S. (2016). (Re)Applying social psychology to organisational work, well-being, and leadership. Journal of Applied Social Psychology, 46, 3-6.

Rockstuhl, T., Dulebohn, J., Ang, S., \& Shore, L. (2012). Leader-Member Exchange (LMX) and Culture: A Meta-Analysis of Correlates of LMX across 23 Countries. Journal of Applied Psychology, 97(6). https://doi.org/10.1037/a0029978

Schappe, S. P. (1998). Understanding Employee Job Satisfaction: The Importance of Procedural and Distributive Justice. Journal of Business \& Psychology, 12(4), 493-504. 
Sharoni, G., Tziner, A., Fein, E. C., Shultz, T., Shaul, K., \& Zilberman, L. (2012). Organizational citizenship behavior and turnover intentions: Do organizational culture and justice moderate their relationship? Journal of Applied Social Psychology, 42, 267-294.

Shirom, A., \& Melamed, S. (2006). A comparison of the construct validity of two burnout measures in two groups of professionals. International Journal of Stress Management, 13(2), 176.

Shirom, A., Toker, S., Melamed, S., Berliner, S., \& Shapira, I. (2013). Burnout and vigor as predictors of the incidence of hyperlipidemia among healthy employees. Applied Psychology: Health and Well-Being, 5(1), 79-98.

Shkoler, O., \& Tziner, A. (2017). The mediating and moderating role of burnout and emotional intelligence in the relationship between organizational justice and work misbehavior. Revista de Psicologia del Trabajo y de las Organizaciones, 33(2), 157-164.

Skarlicki, D. P., \& Folger, R. (1997). Retaliation in the workplace: The roles of distributive, procedural, and interactional justice. Journal of applied Psychology, 82(3), 434.

Smith, D., \& Tziner, A. (1998). Moderating effects of affective disposition and social support on the relationship between person-environment fit and strain. Psychological reports, 82(3), 963-983.

Son, S., Kim, D. Y., \& Kim, M. (2014). How perceived interpersonal justice relates to job burnout and intention to leave: The role of leader-member exchange and cognition-based trust in leaders. Asian Journal of Social Psychology, 17(1), 12-24.

Spector, P. E., Fox, S., Penney, L. M., Bruursema, K., Goh, A., \& Kessler, S. (2006). The dimensionality of counterproductivity: Are all counterproductive behaviors created equal? Journal of Vocational Behavior, 68, 446-460.

Suifan, T. S., Diab, H., \& Abdallah, A. B. (2017). Does organizational justice affect turnover-intention in a developing country? The mediating role of job satisfaction and organizational commitment. Journal of Management Development, 36(9), 1137-1148. https://doi.org/10.1108/JMD-02-2017-0048

Suliman, A. T. (2007). Links between justice, satisfaction and performance in the workplace. Journal of Management Development, 26(4), 294-311.

Swalhi, A., Zgoulli, S., \& Hofaidhllaoui, M. (2017). The influence of organizational justice on job performance. Journal of Management Development, 36(4), 542-559. https://doi.org/10.1108/JMD-11-2015-0162

Taba, M. I. (2018). Mediating effect of work performance and organizational commitment in the relationship between reward system and employees' work satisfaction. Journal of Management Development, 37(1), pp.65-75. https://doi.org/10.1108/JMD-11-2016-0256

Tenhiälä, A., Linna, A., von Bonsdorff, M., Pentti, J., Vahtera, J., Kivimäki, M., \& Elovainio, M. (2013). Organizational justice, sickness absence and employee age. Journal of Managerial Psychology, 28(7-8), 805-825. https://doi.org/10.1108/JMP-07-2013-0246

Till, R. E., \& Karren, R. (2011). Organizational justice perceptions and pay level satisfaction. Journal of Managerial Psychology, 26(1), 42-57. https://doi.org/10.1108/02683941111099619

Tremblay, M. A., Blanchard, C. M., Taylor, S., Pelletier, L. G., \& Villeneuve, M. (2009). Work Extrinsic and Intrinsic Motivation Scale: Its value for organizational psychology research. Canadian Journal of Behavioural Science/Revue canadienne des sciences du comportement, 41(4), 213.

Tziner, A., Bar, Y., Oren, L., \& Kadosh, G. (2011). Corporate Social Responsibility, Organizational Justice and Job Satisfaction: How do They Interrelate, If at All?. Revista De Psicologia Del Trabajo Y De Las Organizaciones, 27(1), 67-72. https://doi.org/10.5093/tr2011v27n1a7

Tziner, A., Fein, E. C., Sharoni, G., Bar-Hen, P., \& Nord, T. (2010). Constructive Deviance, Leader-Member Exchange, and Confidence in Appraisal: How Do They Interrelate, if at All? Revista de Psicología del Trabajo y de las Organizaciones, 26(2), 95-100.

Tziner, A., Fein, E., \& Oren, L. (2012). Human motivation and performance outcomes in the context of downsizing. In C. L. Cooper, A. Pandey, \& J. C. Quick (Eds.), Downsizing: Is Less Still More? (1st ed., pp. 103-133). Cambridge, UK: Cambridge University Press.

Tziner, A., Waismal-Manor, R., Vardi, N., \& Brodman, A. (2008). The personality dispositional approach to job satisfaction and organizational commitment. Psychological reports, 103(2), 435-442. 
Urien Angulo, B., \& Osca, A. (2012). Role stressors, task-oriented norm and job satisfaction: a longitudinal study. Revista de Psicología del Trabajo y de las Organizaciones, 28(3).

Vardi, Y., \& Weitz, E. (2002). Organizational misbehavior: Hypotheses, research and implications. In Re-imaging business ethics: Meaningful solutions for a global economy (pp. 51-84). Emerald Group Publishing Limited.

Viswesvaran, C., \& Ones, D. S. (2002). Examining the Construct of Organizational Justice: A Meta-Analytic Evaluation of Relations with Work Attitudes and Behaviors. Journal of Business Ethics, 38(3), 193-203.

Vroom, V. H., \& Jago, A. G. (1988). Managing Participation: A Critical Dimension of Leadership. Journal of Management Development, 7(5).

Wang, H., Lu, C., \& Siu, O. (2015). Job insecurity and job performance: The moderating role of organizational justice and the mediating role of work engagement. Journal of Applied Psychology, 100(4), 1249-1258. https://doi.org/10.1037/a0038330

Wang, X., Liao, J., Xia, D., \& Chang, T. (2010). The impact of organizational justice on work performance", International Journal of Manpower, 31(6), 660-677.

Weismal-Manor, R., Tziner, A., Berger, E., \& Dikstein, E. (2010). Two of a kind? Leadermember-exchange and organizational citizenship behavior: The moderating role of leader-member similarity. Journal of Applied Social Psych.

Weiss, D. J., Dawis, R. V., England, G. W., \& Lofquist, L. H. (1967). Manual for the. Minnesota Satisfaction Questionnaire. Minnesota studies in vocational rehabilitation, No. XXII. Minneapolis: Industrial Relations Center, University of Minnesota.

White, J. A. (1992). Applying an Experiential Learning Styles Framework to Management and Professional Development. Journal of Management Development, 11(5).

Yau, W. S. L., \& Sculli, D. (1990). Managerial Traits and Skills. Journal of Management Development, 9(6).

Zagenczyk, T.J., Purvis, R.L., Shoss, M.K., Scott, K. L., \& Cruz, K. S. (2015). Social Influence and Leader Perceptions: Multiplex Social Network Ties and Similarity in Leader-Member Exchange. Journal of Business \& Psychology, 30, 105. https://doi.org/10.1007/s10869-013-9332-7

Zangaro, G. A., \& Soeken, K. L. (2007). A meta-analysis of studies of nurses' job satisfaction.

Zimbardo, P. G., \& Leippe, M. R. (1991). The Psychology of Attitude Change and Social Influence. New York: McGraw-Hill.

\section{Copyrights}

Copyright for this article is retained by the author(s), with first publication rights granted to the journal.

This is an open-access article distributed under the terms and conditions of the Creative Commons Attribution license (http://creativecommons.org/licenses/by/4.0/). 